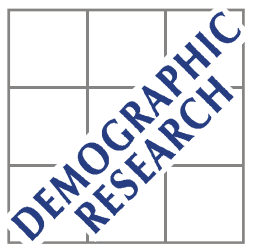

Demographic Research a free, expedited, online journal of peer-reviewed research and commentary in the population sciences published by the Max Planck Institute for Demographic Research Konrad-Zuse Str. 1, D-18057 Rostock · GERMANY www.demographic-research.org

DEMOGRAPHIC RESEARCH

VOLUME 9, ARTICLE 3, PAGES 41-68

PUBLISHED 12 SEPTEMBER 2003

www.demographic-research.org/Volumes/Vol9/3/

DOI: 10.4054/DemRes.2003.9.3

Research Article

\title{
Insecurities in employment and occupational careers and their impact on the transition to fatherhood in western Germany
}

Angelika Tölke

Martin Diewald

(C) 2003 Max-Planck-Gesellschaft. 


\section{Table of Contents}

1 Introduction $\quad 42$

$2 \quad$ Theory and hypotheses $\quad 43$

3 Methods of analyses $\quad 46$

4 Definition of explanatory variables 49

$5 \quad$ Results $\quad 52$

6 Discussion $\quad 56$

$\begin{array}{lll}7 & \text { Acknowledgements } & 58\end{array}$

$\begin{array}{ll}\text { Notes } & 59\end{array}$

$\begin{array}{ll}\text { References } & 60\end{array}$ 


\title{
Insecurities in employment and occupational careers and their impact on the transition to fatherhood in western Germany
}

\author{
Angelika Tölke ${ }^{1}$ \\ Martin Diewald ${ }^{2}$
}

\begin{abstract}
This paper examines the relationship between work and family among men in western Germany. We investigate the extent to which a difficult start in and insecurities during the working life affect men's transition to fatherhood, and the degree to which this effect is influenced by characteristics of the respondent's family of origin and his relationship history.

We use proportional hazards models to analyze data of the third "Familiensurvey" conducted by the German Youth Institute in 2000. In accordance with the spillover hypothesis, which assumes that labor market success (or failure) leads to success (or failure) in family behavior, we found that under difficult and/or insecure circumstances in career patterns, men delay their transition to fatherhood. The delay is caused in particular by unemployment, self-employment or part-time work. A successful career development, however, increases the propensity to have a child soon after having taken a career step. Contrary to the hypothesis of individualization, the social status and the composition of the family of origin still have an impact on the fertility behavior of men in adulthood. In particular, the transition rate to fatherhood is higher if the man grew up with at least one sibling, while losing a parent through death decreases the rate. Both the employment career and the parental home influence the formation of steady relationships, and this explains in part their effect on the transition to fatherhood.
\end{abstract}

1 Corresponding author: Max-Planck-Institute for Demographic Research, Konrad-Zuse-Straße 1, D-18057 Rostock, Germany, phone: (+)49-(0)381-2081-140, fax: (+)49-(0)381-2081-440, toelke@demogr.mpg.de

2 Universität Duisburg-Essen, Campus Duisburg, Fakultät für Gesellschaftswissenschaften, Institut für Soziologie, D-47048 Duisburg, Germany 


\section{Introduction}

Contrary to many expectations, the decision to have a child is still governed to a great extent by the traditional norms of the "golden age of the family", i.e. having children is taken for granted (Burkart 1994, Burkart 2002, Schaeper and Kühn 2000). However, we start from the widely accepted assumption that for an increasing part of the population, having children is dependent on individual and household-based decisions (van de Kaa 1999). Success and failure in the labor market are crucial in these decisions (Huinink 1995, Brüderl and Klein 1993). In modern societies, gainful employment secures unequal access to goods and services. It is therefore not astonishing that a considerable body of empirical research confirms that employment opportunities and failure or success in the labor market affect the transition to parenthood. On the one hand, resources accumulated from the labor market help to deal with the considerable costs and restrictions - in time and money - that parenthood imposes on the opportunity to pursue alternative life goals. The extent to which parenthood may lower individual life goals if financial resources are low is exemplified by the fact that in Germany, raising children is one of the most important poverty risks (e.g., Strengmann-Kuhn 2000). On the other hand, pursuing success in the employment career requires time and energy and may conflict with the norm of "responsible parenthood" (Kaufmann 1988) and modern fatherhood. Thus, patterns and attributes of gainful employment play a key role in explaining the fertility behavior of women and men.

In our paper we examine in particular the impact of working life and different professional careers on the transition to fatherhood for West German men. The link between employment and fertility follows different rules for the two sexes. Especially in a conservative welfare regime like that of Germany, biographical options and constraints are still quite different for women and men, and this applies in particular to the question of how to combine family and work. Hypotheses thus have to be formulated in a different manner for the two sexes and cannot be tested and interpreted in the same way.

When studying the impact of employment on fertility, most empirical research refers merely to the level of education, training and occupational class position or prestige scores. However, in our paper we will show that these indicators are not sufficient in capturing the impact of employment on fertility in two respects. First, they rely too heavily on the assumption of stable careers and predictable career prospects. They neglect the fact that employment contracts and career prospects differ not only according to material and immaterial gratifications but also according to the amount of predictability and security they provide for the workforce. Examples are fixed-term contracts as they introduce a degree of insecurity in the future career pattern, and the difference between relatively secure public service employment and unpredictable 
private business employment. The indicators do not take into account that work-life careers have become less stable and more heterogeneous as far as working conditions, income prospects, and job security are concerned. These factors define "new" lines of labor market inequalities that are not adequately represented by class typologies, status or prestige scores. To what degree insecurities and discontinuities in labor market participation and careers actually increased since the 1980s is still debated (Neumark 2000, Diewald 2003). But disregarding whether there was a considerable change of this kind or not, this important dimension of labor market inequalities has been neglected in previous research. Second, occupational class position or status, even if they are measured time-dependently, do not capture adequately the life course logic of rational behavior. The life course is a cumulative, endogenous process of causation, with former experiences affecting later decisions (Mayer 2003). Comparisons of one's own career experiences with normative expectations and aspirations play an important role. For these two reasons we aim to extend the traditional approach by including various indicators of the accumulation of former job and career stability and security experiences in our analyses of the transition to fatherhood.

\section{Theory and hypotheses}

To investigate the impact of working life and employment careers on the transition to fatherhood, we refer to a general theory of goal-oriented and rational behavior (Lindenberg 1996, Ormel 2002) and some of its adaptations to demographic processes in the life course (c.f., Easterlin 1987, Leibenstein 1975, Birg et al. 1991). From this family of general theories, we borrow two assumptions. First, we assume that the male breadwinner model is still a prevailing normative task. In this case, securing economic resources as precondition for establishing a family is a rational behavior for men. Second, pursuing competing life goals (like economic or occupational success as subgoals of social agency versus having a child as sub-goal of belonging and bonding) depends on the salience of these goals and the expected probability that the respective goal can be achieved successfully. The latter in turn is dependent on the availability of resources and competences.

With Easterlin (1987) and Leibenstein (1975) in particular we share the assumption that individual behavior is heavily influenced by social comparisons with reference groups. Easterlin focused on the economic well-being of the family of origin, Leibenstein on the living conditions of reference groups within the same birth cohort. In this article, we focus on insecurities and instabilities in the occupational career where aspirations acquired by educational attainment and training and the expectation of "normal" (in the sense of institutionalized) career prospects play a major role. 
In general, at the individual level, three different kinds of hypotheses about the possible interrelation between work life and family behavior can be distinguished (Zedeck 1992). The hypothesis of a "spillover" effect of work life on family behavior, as represented by the fact that men with low educational levels also have low fertility (Huinink 1995), stands out as the most prominent in the relevant literature. In the case of a "spillover", labor market success (or failure) leads to success (or failure, respectively) in family behavior. For our question concerning the fertility of men, this means that full-time employment, good working conditions and career advancement as well as job and career security should facilitate the transition to fatherhood, since they are important resources for dealing with the long-term strains, liabilities, and commitments of raising children. Vice versa, part-time and/or temporary work, downward mobility, a low level of employment stability, and a mismatch between a relatively low occupational position and a relatively high level of education all should weaken the capability of men to take over such responsibilities. This expectation should be especially true for Germany. First, in Germany the gender-specific division of labor is still more traditional than in almost all other western societies, with men working full-time and women working part-time or being non-employed in the case of motherhood (Pfau-Effinger 2000, Blossfeld 1997). Thus, a stable and successful career is most important to take over the role of the male breadwinner. Second, job insecurity is in Germany more than in most other western societies an awkward event that people are not used to and which makes them feel unsure. Industrial relations and career prospects are traditionally based on trust and reliability, and transmitted by a stable inclusion in firms and occupational milieus (Soskice 1993). More generally speaking: As in the spillover hypothesis, the loss of stability and predictability weakens the readiness for stable, long-term commitments in relationships (c.f., Sennett 1998). This is the prevailing and often confirmed sociological hypothesis of the importance of unequally distributed resources (material, status reputation) for nearly all other social participations in life.

However, with some plausibility one can also formulate the alternative hypothesis of a compensatory relationship between work and fertility (Zedeck 1992). This is because of a possible substitution at the level of life goals or at the level of available means to achieve the same life goal. Four arguments support the compensation hypothesis. First, the strains resulting from a long period of education and training and a challenging and laborious career may restrict the propensity and ability of men to play an active role as father above the mere breadwinner role. Unlike their attitudes toward housework, fathers are nowadays more often expected to commit themselves to spending time with their children than it was the case a few decades ago. Second, expected returns of investments in the occupational career rise like a spiral with early successes (Merton's "Matthew effect"). In this case, too, a substitution of life goals may 
occur, with occupational success replacing informal social belonging. And third, a discontenting job and career situation may intensify the desire to look for a steady and fulfilling personal relationship. In this case, people with high resources who usually aspire to achieve social recognition more than other people shift their priorities to life goals of striving for emotional warmth and belonging to close friends. In a fourth, similar argument, the compensation does not refer to the differential salience of general life goals, but to the availability and probability of different ways to achieve this goal, namely belonging, trust and reliability. The experience of insecurity in the labor market may actually strengthen the need for trust and reliability in personal relationships. This compensatory reaction is the direct counter-hypothesis to Sennett's (1998) assumption that experiences of instability in the labor market inhibit the readiness or ability to invest in stable personal relationships. The more the principle of stable social inclusion is weakened by changes in the labor market or at work, the more one has to rely for such experiences on informal social relationships. The parent-child relationship is the prototype of such a relationship, since it is the most indissoluble relationship of all.

Moreover, the compensatory and spillover hypothesis may not be contradictory assumptions but may complement one another in explaining a non-linear relationship between gainful employment and the transition to fatherhood. It is especially for men who are at the bottom of the hierarchy in the labor market and who have insecure working contracts that a compensatory relationship is most likely to be entered, because they have nothing to lose but something to win by investing in parenthood. Waiting for better economic conditions by accumulating resources and getting a secure workplace during their career to cope later on with the liabilities of parenthood may not be a realistic option for them. For all other men in the workforce, however, the spillover hypothesis may prevail, since establishing a stable, secure, and more or less successful career is a normative expectation and at the same time a precondition for a family life with an adequate standard of living. For these people, the compensatory route should become more relevant only if occupational success has to be paid by extraordinary efforts conflicting with the everyday joys and duties of fatherhood.

Despite these arguments in favor of a spillover or compensation effect, we can formulate the expectation of work-life and family development segmentation. Neither life domains influence each other nor are the developments in the life domains caused by another joint factor. We admit, however, that this is quite unlikely for western market societies, where labor market integration plays a key role for all other social participations. If we had included the former GDR, with its extended system of social security and very low labor market risks (Mayer and Diewald 1996) in our analyses, this third hypothesis would have more weight.

Finally, statistical correlations between work and family events may not indicate a causal relationship but only a spurious correlation caused by other factors like 
personality characteristics or earlier life experiences of insecurity and instability. Thus, low fertility and low performance in the labor market could both be caused by low abilities and lacking personal efforts or by the experience of a fragmented family of origin. The individualization-hypothesis pretends - among other things - that the family background and the cultural context lose power in structuring people's life courses (e.g. Beck 1986, in a critical perspective Friedrichs 1998). Security and stability in life, which were once achieved by traditions and norms, are losing their meaning as aid of orientation. The individual is confronted with a variety of options in life and has the chance to choose between different life tracks. People are becoming the architects of their own lives. According to this hypotheses, one can assume that the social status of the family of origin as well as early experiences in the family or in the cultural context have lost their importance for structuring the transition to fatherhood. In this paper, we do not discuss this theoretical approach in detail as we mainly focus on the impact of working life on having a first child. The characteristics of the parental family and of the cultural context have a controlling function in our study.

A specific problem of analyses of the transition to parenthood is that correlations of this life event with men's employment characteristics may interfere with the forming of partnerships, marriage, and assortative mating, in particular the female partner's education and labor force participation. A steady relationship is essential for men to start a family, and in western Germany, marriage is an important normative precondition of parenthood. Having children while cohabiting is still an exception (Höpflinger 1997). One would be interested in knowing the impact of different kinds and degrees of formalization of relationships on the transition to fatherhood. But marriage and the birth of a child are closely related to each other. Chronologically, marriage usually still precedes the transition to parenthood, but the decision to marry is often made with the desire to start a family. Therefore it is substantially as well as statistically highly problematic to include marriage as an exogenous, explaining factor. We will discuss these problems in more detail when presenting our empirical design and the results.

\section{Methods of analyses}

\section{Sample selection}

Our empirical analyses use data from the third German "Family-Survey" conducted by the German Youth Institute (Munich, Germany) in the year 2000 in eastern and western Germany. About 10,000 men and women were interviewed. The sample is representative for Germany and contains detailed retrospective information on the 
employment and professional career of the respondents, on their intimate relationships and family development. Unfortunately, not all events have exactly corresponding dates. With some professional career changes, we know the year but not the month the change occurred. This necessitated a more crude construction of time varying covariates employed in the statistical model that is on a yearly base.

We use a sub-sample of this survey, namely men from western Germany born in 1946-50, 1951-55, 1956-60, 1961-65 and 1966-70. We confine ourselves to western Germany as the labor market crisis in eastern Germany caused by unification hit the life course of the selected birth cohorts at different life stages and therefore affected their lives in different ways. It would be necessary to run separate analyses for the youngest birth cohort in eastern Germany but our sample number is too small to do this. In addition, it would shift the emphasis of our analyses to the effects of unification.

As we are primarily interested in the impact of employment careers on the transition to fatherhood, we further restrict our sample to men who had at least one job. Men who had a child before starting their working lives (6\%) are excluded from the analyses, as the event of interest occurred before the working life could exert an influence on it. The remaining sample size for our analyses includes 1,600 men in western Germany. The transition to fatherhood is defined as "becoming the father of one's own first child". Children from other relationships of the partner were not taken into account because the respondent neither participated in the decision to have these children nor in the timing of his partner's children. We are aware, though, that the existence or non-existence of a partner's child from a previous relationship does make a difference in one's own fertility decision (Thomson 1997). Nevertheless, the number of men without an own child who start a relationship with a mother is very small in our sample. Beyond this, including information on the stepchild into the model would only differentiate and specify the effect of the relationship, which is not the main emphasis of our paper.

\section{Data and method}

The dependent variable is the transition to first fatherhood. We do not consider the year of the actual birth as the point of transition to fatherhood, but rather the calendar year before the birth so that we arrive at the approximate time the actual decision to have a child was made. We also constructed the employment history based on years rather than months owing to limitations of the data: Some job changes were not collected on a monthly base. A year-based construction ensures the proper sequencing of the events. 
The probability for the transition to fatherhood changes over time during the working life. At the start of the working life (e.g. a new job), the hazard rate for establishing a family is probably lower than some time into a job. However, as the timedependency of that development is not clearly defined, we use the proportional-hazardsmodel for the analyses on the transition to fatherhood (Cox 1972). We further assume changing probabilities on the transition to fatherhood when there is a change in the employment status (unemployment; employment interruption due to further educational training) or in the professional career (upward or downward movement). We construct time-varying covariates to ensure that these changes are included into our model specification. A crucial impact on the transition to fatherhood needs to be postulated when a change occurs in the existence and the kind of a relationship (living apart together, cohabitation, and marriage). Yet the modeling of the link between the two kinds of events rises two questions. We mentioned above the problem of interdependence of marriage and parenthood. A second problem is whether men without a partner are really "at risk" (Note 1) to become a father in a social sense. Certainly such a planning process to which most of our theoretical reasoning applies is normally linked to the existence of a more or less enduring relationship. On the other hand, and this might be especially the case in the situation of economic security, even in new partnerships after a short time the wish to have a common child may override explicit decision-making. To deal with both problems we changed the sampling as well as the process time in our model specification when including cohabitation and marriage as time-varying covariates.

In a first step all men independently of having had any relationship are included into our analyses (see Model 1 in Table 2). The observation starts with the entry into the labor market. But as mentioned above being in a relationship is usually essential for planning and having a family. We therefore run a separate model with the same covariates, but excluding all men who have never been in a steady relationship, which means in our case having had no relationship lasting at least one year up to the time of the interview (see Model 3 in Table 2). In this model specification the process time starts at that point in time when both of the following two criterions are met: a man has started his professional career as well as has started a relationship. For those who already had a partner when they started their first job the process time starts with their entry into the labor market. For those who formed a relationship only later the process time starts in the year when having a first partner while already being in the labor market. How the coefficients of the previous model specifications change when information on cohabitation and marriage get included is finally shown in Model 4 (see Table 2). As marriage and parenthood often coincide the effect of marriage should not be interpreted as an exogenous event but as a part of family formation. With this model it can be recognized whether factors influencing parenthood are also effective for 
partnership formation and marriage. The process time is the same as before, which means that the transition to fatherhood is estimated conditional on having started a professional career as well as on partnership formation. In all model specifications the process time runs up to the event of interest, that is, the transition to fatherhood, or up to the time of the interview.

\section{Definition of explanatory variables}

\section{Men's career development}

We study several aspects of the employment career on the transition to fatherhood. First, at the level of labor force participation, we use a time-varying covariate distinguishing between periods of employment and periods of not being employed, and for the latter we make a distinction between unemployment and education. Periods of unemployment are usually accompanied by current economic difficulties and by insecurities concerning future career and professional development. We assume that difficulties and insecurities are more pronounced during periods of unemployment than during employment breaks resulting from educational training. As far as employment periods are concerned, we make a distinction between full-time and part-time work indicating the degree of integration into the labor market. At least for men, part-time employment is synonymous with not being fully integrated into the labor market and is therefore not desired. Part-time work could have been included as a time-varying covariate, and we have done this previously. However, as the number of men who worked part-time is very small, this characteristic is now included as a time-constant variable in order to simplify the model.

Second, at the level of occupational status, self-employed people have no contractual employment guarantee per se. Especially when they are starting a business of their own, they are fully exposed to the harsh reality of changing market forces. Setting up and running a business requires a great deal of investment in terms of time, energy, and money. We therefore assume that there are lower transition rates to fatherhood for self-employed men. The variable 'self-employment' indicates as a timeconstant covariate whether someone has been self-employed or not during one of his first five jobs before first fatherhood. From previous analyses we learnt that selfemployment seems to require certain personality traits, which not only show up in periods of self-employment but are also virulent in employment spells prior to and following self-employment (provided that the respondent does not stay self-employed all his working life). 
Third, the categories of the rank order variable "professional career" are based on a transformation of the widely used German "Occupational Status Classification" (Note 2) (see Table A1). The "Occupational Status Classification" includes both employment status and occupational function and takes into account such factors as source and level of income, job security, and the degree of autonomy at work. The 19 categories of this partially ordered list are transformed into eight ordinal career ranks (for similar approaches, see Hoffmeyer-Zlotnik 1993). The main determinants for this transformation are the educational requirements for entry-level access to a position and the extent of supervisory and/or managerial authority. For the purpose of the following analysis, career mobility is defined as "moving to a higher (or lower) career rank for the first time compared to the career rank of the job held before" (Note 3). As long as someone occupies that higher career rank (or even moves up again), the corresponding time-varying career-variable continues to stay the same, which means the variable has the value " 1 ". If a job change implying a downward movement has occurred after a previous upward movement, the covariate "upward mobile" turns into " 0 " and the covariate "upward - downward" turns from " 0 " to " 1 ". The downward mobility and a mixed pattern of down- and upward movements are constructed in the same way. Downward mobility means that there is some sort of life course discontinuity, since it indicates difficulties in accumulating labor market resources consistently or gathering the fruits of former investments. For a further specification of the immediate, mediumand long-term effects of these events on the transition to parenthood, one would need to have more theoretical and empirical evidence for classifying periods affecting the start of a family. Periods might be different for various occupations and might interact with age. With the current state of knowledge, the construction would be arbitrary

Life course discontinuities can also be defined by the level of the first job in relation to former investments in education and training. A time-constant variable evaluates the translation of educational attainment into the first occupational position (see Table A2). A negative start into working life means that the position of the first job is lower than one would expect from knowing the educational level. We assume that this forces men to improve their occupational status. This situation, as well as a positive start into the working life which places great demands on the respondent to justify his occupational placing, is supposed to result in a postponement of fatherhood. The variable "permanent contract" distinguishes between three periods of employment until the first fixed-term contract is entered, namely the beginning/the first year, the second/third year and the third/fourth year or following. The variable "fixed-termed contracts" is also seen as indicator for a difficult career entry pattern, causing insecurities about the future career development. Both variables might also be indicators for women to assess a man's "career maturity" and his readiness to start a family (Oppenheimer and Lewin 1997). However, without additional information, the 
contract characteristic may not be a satisfactory indicator of job insecurity, since a fixed-term contract can often be an entry-point to long-term jobs and to a promising career ladder within firms.

Downward mobility, fixed-term contracts, part-time work and employment below the level of training acquired are often said to be "new", destandardized forms of employment which have been growing rapidly in the past years in modern societies (Kalleberg et al. 2000, Diewald and Konietzka 1998). However, there is still no agreement about the range, causes, and consequences of such a trend (Neumark 2000). In the light of our theoretical framework, we would have liked to have time-varying indicators of work strains in our database. Yet we were not able to do so owing to data limitations.

The educational attainment covers the qualification upon leaving school, combined with the kind of professional training gained before entry into the labor market.

\section{Family background, socio-demographic characteristics, and relationship history}

Characteristics of the family of origin include the educational attainment of the father at age 15 of the respondent, the family structure, and whether the respondent had at least one sibling. The structure of the family of origin indicates whether the respondent grew up with both parents, experienced parental loss by death or whether the parents got divorced (this includes single parenthood). It provides us with details concerning experiences of (in)stability in intimate relationships. Siblings may indicate that the respondent's parents have or had a stronger family orientation, and it provides the respondent - as a child as well as an adult - with additional social experiences in close relationships. Having siblings can decrease economic resources for each child, which may result in early marriage (Michael/Tuma 1985), and it may raise the probability of parenthood by producing some kind of competition among siblings to produce grandchildren for one's parents. The educational attainment of the father can be distinguished by three categories, the lower secondary school (with or without training) is the most common one and we used it as the reference category. The father's educational characteristic points to resources available to the respondent, as well as to normative demands at least to maintain the social status of the family of origin.

Religious denomination is included as an indicator for the cultural context. The (non-) possession of the German nationality has been omitted because of its high correlation with the categories of religious denomination. The selected birth cohorts included in our study experienced a period of change in fertility behavior, which we control for in the cohort-variable. Knowing the age of the respondent, we investigate whether the transition to first fatherhood is a lifelong opportunity, which men make use 
of or whether it is a socially limited period in men's life - the equivalent of a biologically limited period for women.

In Model 4 we include cohabitation and marriage as time varying variables conditional on having started partnership formation. In the retrospective questions of the survey, only relationships lasting at least one year were taken into account.

\section{Results}

$63 \%$ of all West-German men of our selected birth-cohorts had at least one child at the time of the interview. From the descriptive results of Table 1, we learn in general that men with employment insecurities have a lower percentage of fathers, whereas being continuously employed seems to improve the starting-position for having a child. A steady career development is linked with a higher percentage of fathers, compared to those who experienced up- and/or downward movements before their first child was born (respectively before the time of the interview). The variables indicating a difficult start in the working life do not generate much difference in the distribution of being a father or not. Differences in the family of origin and the cultural context seem to produce variations in different fertility patterns.

We now turn to the empirical results from our Cox regression analysis of the transition to first fatherhood, based on four model specifications (see Table 2). In the first step, we included only characteristics of the educational attainment, the employment development as well as the professional career in order to see their specific impact on the transition to fatherhood. In Model 2 (Table 2), we then added information on the parental home and on religious denomination. These two models are based on all men having started their first job. In Model 3 the population being at risk is more narrowly defined: Only men who in addition have ever had a steady relationship were selected. Comparing the parameter estimates between Model 2 and Model 3 one can find out what characteristics of the employment career still have an impact after having started relationship which means that these factors are not absorbed by partnership formation. In a last step (Table 2, Model 4) the impact of formalizing a relationship by marrying in comparison to cohabiting is analyzed using the same sample selection as well as process time as in Model 3. Here we try to identify possible conjoint effects of employment characteristics on partnership formation and on fatherhood. We assume that the partnership covariates will have the strongest impact and that they will possibly superimpose some of the effects of the previously included variables. Specifically, significant effects in Models 1 to 3 may prove to be effects additionally linked with union formation. As mentioned above, in western Germany, with its relatively small percentage of cohabiting couples with children, marriage is in many instances a 
consequence of anticipated parenthood. In all three model-specifications, we control in addition for birth cohorts and the age of the respondent.

Insecurities during the working life and a difficult start in the working life do have an impact on the transition to fatherhood, though this does not hold true for all our indicators of discontinuities and insecurities (Table 2; Model 1). Under difficult or insecure circumstances, men delay the start of a family (Note 4). Self-employment, part-time work, and periods of unemployment are particularly crucial. In some ways, unemployment is an inherent phenomenon of the labor markets of free market economies but there are some aspects that recently have changed or at least become more pronounced in Germany. Structural unemployment has emerged periodically since the 1970s, and it has increased and become more widespread since the 1990s. More people with all kinds of jobs are potentially at risk of becoming unemployed. Even the well-trained are affected, though to a much lesser degree than those with low education. Our results show that not being gainfully employed reduces the transition to fatherhood significantly. Insecurities resulting from not being employed and uncertain prospects for the (near) future reduce the likelihood for parenthood. This is in accordance with the spillover-hypothesis, which postulates that insecurities in the working life carry over into the private life, postponing or preventing long-lasting commitments. As men in western Germany still see themselves and are regarded as being the breadwinner of the family, they shy away from family responsibilities when their economic situation is insecure. Being in education - after having started a professional career already reduces the transition rate to parenthood for men to a significant amount as well. Further education is an investment in one's future professional career but has not yet been turned into money or some other reward. Beyond this, it is contradictory to social norms to start a family while in education.

Another factor indicating insecurity is self-employment. From previous analyses we learnt that the impact of self-employment does not have a pronounced immediate impact, but rather an enduring one (Tölke and Diewald 2003). It proved to be a characteristic of the personality that already shows up before becoming self-employed and is still effective after ending a self-employment period. For this reason, we included information about setting up a business, using it as a time constant instead of constructing a time-varying variable. Having been self-employed in one of the first jobs causes significantly lower transition rates to fatherhood than having had no experiences in self-employment. Self-employment usually requires money and preparation in advance, and plenty of time and energy is needed to run a business. This may lead to the postponement of family formation.

The following dimensions of the professional career characterize a difficult, challenging or precarious start to the working life - in a strict sense, these are "new insecurities". One of our indicators covering "new insecurities" is part-time 
employment early in the working life. Confirming our hypothesis, part-time work significantly reduces the propensity and certainly the chances of starting a family in the first two models (c.f., Table 2). In Model 3, however, the coefficient is no more significant. Apparently, this indicator interferes not only with childbirth but also with building up a relationship. Obtaining a permanent contract only later in one's employment career and experiencing a negative or positive start in the working life, however, do not affect the transition to fatherhood to a significant degree. Only a small number of men in our sample mentioned one or more of these experiences in their former working lives. This might contribute to the fact that the statistical significance level is not reached.

Focussing on career development as a process, we learn that only one career track has an increasing impact on the transition to first fatherhood, and that is upward movement. We find a clear difference between men who have experienced an upward movement and those who remained on the same career rank. In Models 1 and 2, the probability of becoming a father is significantly higher for those men who climb up the career ladder than for those on a steady track. This feature may be attributed to a timing effect. Upwardly mobile men (have to) postpone the founding of a family because long educational periods and investment in the career take time. But if they succeed, the probability of establishing a family is no longer low, and they catch up with high speed. This effect remains significant in Model 3 where the process time starts with the first relationship while already employed and even in Model 4 where we include cohabitation and marriage. The results concerning the upward career track support one aspect of the spillover hypotheses, namely that success in the labor market is passed on to family behavior. This does not apply to the other aspect of spillover, the failure. Men who are downwardly mobile and those with mixed career patterns do not have significantly different probabilities.

A medium and high educational attainment reaches significance only if the characteristics of the family of origin are included which means there is a suppressoreffect. (Table 2; Model 2). A medium or high school-leaving qualification followed by vocational training and the degree of an upper secondary school with an apprenticeship or a university-degree then results into a high probability for a transition to fatherhood compared to those who have a basic education only (reference group: lower secondary school with vocational training). The effect of an upper secondary school qualification diminishes when the process-time starts with having a partner that means it affects the start of a relationship but not becoming a father (Model 3). Only the medium schoolleaving qualification remains significant. This means that the higher probability for well-educated men to become a father is underestimated when not controlling for their background. Contrary to the assumption of a compensatory effect between work and 
family for lowly educated men they do not have a significantly higher propensity to become father.

Although it is often assumed that modernization and individualization diminish the impact of the family of origin on one's own future life, our results still show its persistent importance (Table 2; Model 3 and 4). This includes, in particular, the experience of having had siblings. This effect holds true even if one's own relationship history is controlled for (Table 2; Model 4). It is already known that siblings have a positive effect on the propensity to establish one's own family (Michael and Tuma 1985; Huinink and Wagner 1989). This might be a manifestation of adopting the family orientation of one's own parents as well as an expression of important social experiences within the family. Growing up as a single child lowers the rate of transition to parenthood significantly. Non-stability in the family of origin reduces men's transition to fatherhood. Losing a parent by death reduces the likelihood of having a first child. Since we control for the father's education, it does not seem to be the economic situation but rather some kind of emotional or psychological vulnerability earlier in life which results in a lower probability to have one's own family. Steady relationships respectively partners do not neutralize the effect of previous sociopsychological experiences of unstable close relations.

The father's level of educational attainment continues to have an impact on men's lives when they are grown up. If the level of attainment is above the most common educational level, it reduces the son's transition rate to fatherhood. Especially medium educational level of the father has a significantly decreasing effect (Table 2; Model 4). High expectations of the family of origin to maintain or to improve the social status of the family of origin and to give one's own family a safe financial foundation may result in a postponement of fatherhood at least. A father's university degree points in the same direction, but falls just short of the significance level.

Comparing the estimates between the different model specifications gives some hints on the independent and joint effects of the selected variables on fatherhood and relationship formation. Changes in the coefficients between Model 2 and 3 indicate that some of the job insecurities, i.e. part-time work and participating in further education, get absorbed when having started one's partnership biography. This indicates that those insecurities diminish the forming of steady relationships but not the transition to fatherhood itself. When cohabitation and marriage are included as separate variables (Model 4) we get the expected empirical evidence that formalizing a partnership is still a crucial step when establishing a family. The transition rate to parenthood increases with the degree to which the relationship is institutionalized, with the highest rate - that is more than four times higher than in periods of cohabitation - when married (Table 2; Model 4). Here again we would like to point to the fact of possible reversed causality, 
which means that the institutionalization of a relationship into a marriage often takes place because of anticipated parenthood.

In Model 4 unemployment loses its significance and some of the other characteristics as well. Again, these variables affect probably both, the transitions to fatherhood as well as to marriage, because these events have to be seen as a "package" when establishing a family in western Germany as pointed out above. Beyond unemployment the hampering impact of being younger than 20 years, being a member of the youngest birth cohort born in the late 1960s, and being a member of a nonChristian religion for establishing a family disappear. Again, these facts affect both marriage and fatherhood most likely conjointly.

Now and then, men past their middle age make headlines in the media when they become fathers. To become a father at such late an age is the exception to the rule, however, at least as far as the first child is concerned. Men who are older than 35 have a significantly lower probability for a transition to fatherhood than young men between the ages of 25 and $30 \mathrm{do}$, which is the reference age in our model. This effect holds true in all our model specifications. A postponement of the decision to have a child seems to be limited - even for men.

There is a general trend to postpone the start of a family. Looking at Models 1 and 2 (Table 2), we see that the two youngest cohorts born in the late 1960s postpone the start of a family. This effect still stays significant in Model 3 when only men are included who ever had a partner and the process time for becoming a father starts when important steps to adulthood are mastered, namely employment and relationship. But continuing to Model 4, where the entering of cohabitation and marriage is included, the cohort-effect diminishes. This means that the timing of (most probably) a marriage most likely in conjunction with the wish to have a child - evokes the cohort effect.

Religious denomination, as an indicator for the cultural context, points to the postulated direction. Only Muslims (including other non-Christian religions) have a higher propensity to establish a family, most probably including marriage and parenthood.

\section{Discussion}

A difficult start in and insecurities during the working life delay the transition to fatherhood, though this does not hold true for all our indicators of discontinuities and insecurities. Self-employment, part-time work and periods of unemployment are particularly crucial. This is in accordance with the spillover hypotheses, which postulates that success and failure in the working life affect the private life in the same way. The other characteristics indicating insecure or difficult career development do not 
reach statistical significance. This includes a negative or positive start in the working life (compared to the educational attainment), getting a permanent contract only later into one's employment history, a low educational attainment and an unsuccessful career track. A difficult start into the working life seems to have no long-lasting effects but also small numbers might cause the fact that these variables do not reach statistical significance. Working part-time and pursuing one's studies postpones steady relationships but when having mastered the step to steady relationship these factors lose importance. Being unemployed on the other hand is still effective in partnerships and reduces the propensity resp. the chance to start a family, marriage and parenthood. Selfemployment and upward mobility are the only characteristics of the working-life, which keep up their crucial status even when the kind of relationship is included in the model specification. Self-employment reduces the realization of fatherhood significantly and a career step has a beneficial effect on it. According to our result "breadwinner-qualities" still play a decisive role in establishing a family. We found, however, no results supporting a compensatory relationship between work and family formation. The current development of the labor market reinforcing less security and fewer steadiness may have a non-trivial impact on the development of fertility in Germany. The comparatively low fertility rate may even drop further if the labor market problems cannot be solved.

In contrast to some individualization assumptions the social status as well as the composition of and experiences in the family of origin still affect the course of one's adult life. The loss of a parent makes a man's transition to fatherhood more difficult. We interpret this effect as an expression of a psychological and emotional vulnerability and a loss of trust in enduring intimate relationships. The companion part is growing up with both parents and having at least one sibling. This - decreasing - prototype of a complete and enduring family supports the start of one's own family.

Furthermore steady relationships seem to decrease or even neutralize the effects of some difficult labor market experiences as well. However, the link between labor market, union formation and fertility has to be extended in several respects. Characteristics of the partner should be included in further research to assess the impact of assortative mating and to find out what characteristics of the partner in particular can cancel out economic insecurities and can increase men's transition to fatherhood on this new intimate basis. Furthermore, the process of union formation should be analyzed. Comparing results of the transition to marriage and to fatherhood can elucidate what factors are effective and when. This might be done by running separate models or preferably by using multi-process-modeling techniques (Lillard 1993). 


\section{Acknowledgements}

We thank Jan Hoem, Andres Vikat, and three anonymous reviewers for their helpful comments on earlier versions of this paper, Rainer Walke for his help in constructing the data file, and Susann Backer for correcting our English wording. 


\section{Notes}

1. The period until becoming a father is technically called "time at risk". We will use the expression "process-time" instead in the following because of its more neutral meaning.

2. This classification was first used by the German Census Bureau in 1971 (MZU71) and has become a standard component in social science surveys in Germany. Pappi 1979 provides a detailed discussion of the underlying concepts and related operationalizations. The general practice in career mobility research is to use an occupational prestige ranking (e.g. Treiman-Scale, Wegener-Scale). In these rankings, the occupational activities are scored, but the status or the position in the hierarchical dimension are not. As our focus is the hierarchical dimension, we did not use a prestige ranking scale.

3. Of course, this simple typology of just eight career levels does not capture all career advancements, but neither does the original classification.

4. We use this phrase as well as family formation as a synonym to transition to first fatherhood 


\section{References}

Beck U. (1986): Risikogesellschaft. Auf dem Weg in eine andere Moderne. Frankfurt/M.: Suhrkamp Verlag.

Birg H. Flöthmann, E.-J., and Reiter, I. (1991): Biographische Theorie der demographischen Reproduktion. Frankfurt/M.: Campus.

Blossfeld H.-P. (1997): Women's part-time employment and the family cycle: A crossnational comparison. In: Blossfeld, H.-P. und Hakim, C. (Hgs.): Between Equalization and Marginalization. Part-time Working Women in Europe and the United States. Oxford: Oxford University Press, 315-323

Brüderl J. and Klein T. (1993): Bildung und Familiengründungsprozeß deutscher Frauen: Humankapital- und Institutioneneffekt. In: Diekmann A. and Weick S. (eds.): Der Familienzyklus als sozialer Prozeß. Bevölkerungssoziologische Untersuchungen mit den Methoden der Ereignisanalyse. Berlin: Duncker und Humblot, 194-215.

Burkart G. (1994): Die Entscheidung zur Elternschaft. Eine empirische Kritik von Individualisierungs- und Rational Choice-Theorien. Stuttgart: Enke.

Burkart G. (2002): Entscheidung zur Elternschaft revisited. Was leistet der Entscheidungsbegriff für die Erklärung biographischer Übergänge? In: Schneider, N.F. and Matthias-Bleck H. (eds.): Elternschaft heute. Gesellschaftliche Rahmenbedingungen und individuelle Gestaltungsaufgaben. (Zeitschrift für Familienforschung, Sonderheft 2), Opladen: Leske und Budrich, 23-48.

Cox D. (1972): Regression Models and Life Tables. In: Journal of Royal Statistics (Series B), 34, 187-202.

Diewald M. (in press): Die zukünftige Entwicklung neuer Formen der Erwerbsarbeit Thesen vor dem Hintergrund sozialer und demographischer Entwicklungen: In: Behringer F. et. al. (eds.): Diskontinuierliche Erwerbsbiografien - Realität oder Konstrukt? Perspektiven aus Sozialwissenschaft und Erwachsenenbildung. Hohengehren: Schneider.

Diewald M. and Konietzka D. (1998): Beschäftigungsverhältnisse und die Analyse von Arbeitsmarktprozessen in den 90er Jahren - Probleme der Messung von Karrieremobilität in einer sich verändernden Arbeitswelt. In: Schupp J. et. al. (eds): Arbeitsmarktstatistik zwischen Realität und Fiktion. 
Beschäftigungsverhältnisse in einer sich wandelnden Arbeitswelt. Berlin: edition sigma , 269-298.

Easterlin R. A. (1987): Birth and Fortune. The Impact of Numbers on Personal Welfare. Chicago: The University of Chicago Press.

Esping-Anderson G. (1991): The Three Worlds of Welfare Capitalism. Princeton, NJ: Princeton University Press.

Friedrichs J. (1998): Die Individualisierungs-These. Opladen: Leske + Budrich.

Höpflinger F. (1997): Haushalts- und Familienstrukturen im intereuropäischen Vergleich. In: Hradil, S./Immerfall, S. (eds.): Die westeuropäischen Gesellschaften im Vergleich. Opladen: Leske+Budrich, 97-138.

Hoffmeyer-Zlotnik J. (1993): Operationalisierung von "Beruf" als zentrale Variable zur Messung von sozio-ökonomischem Status. ZUMA-Nachrichten 32, 135-141.

Huinink J. (1995): Warum noch Familie? Zur Attraktivität von Partnerschaft und Elternschaft in unserer Gesellschaft. Frankfurt/New York: Campus.

Huinink J. and Wagner M. (1989): Regionale Lebensbedingungen, Migration und Familienbildung. In: Kölner Zeitschrift für Soziologie und Sozialpädagogik, 4, 669-689.

Jones G. and Wallace C. (1992): Youth Family and Citizenship. Milton Keynes, England: Open University Press.

Kaufmann F.-X. (1988): Familie und Modernität. In: K. Lüscher et al. (eds): Die 'postmoderne' Familie. Konstanz, 391- 416.

Kalleberg A.L. et al. (2000): Bad Jobs in America: Standard and Nonstandard Employment Relations and Job Quality in the United States. In: American Sociological Review, 65, 256-278.

Kiernan K. (1995): Transitions to Parenthood: Young Mothers, Young Fathers Associated Factors and Later Life Experiences. Unpublished paper.

Leibenstein H. (1975): The Economic Theory of Fertility Decline. The Quarterly Journal of Economics 89, 1-31.

Lillard L.A. (1993): Simultaneous equations for hazards. Marriage duration and fertility timing. In: Journal of Econometrics 56, 189-217. 
Lindenberg S. (1996): Continuities in the theory of social production functions. In: H. Ganzeboom, H. and Lindenberg, S. (eds.), Verklarende Sociologie; opstellen voor Reinhart Wippler. Amsterdam: Thesis Publication, 169-184.

Mayer K. U. (2003): The sociology of life course and lifespan psychology: Diverging or converging pathways? In: Staudinger U.M. and Lindenberger U. (eds.): Understanding human development: Dialogues with lifespan psychology. Dordrecht: Kluwer Academic Publishers, 463-481.

Mayer K. U. and Diewald M. (1996): Kollektiv und Eigensinn. Die Geschichte der DDR und die Lebensverläufe ihrer Bürger. In: Aus Politik und Zeitgeschichte $46,8-17$.

Michael T. R. and Tuma N.B. (1985): Entry into Marriage and Parenthood by Young Men and Women: The Influence of Family Background. Demography, 22, 4, 515-544.

Neumark D. (2000): Changes in Job Stability and Job Security: A Collective Effort to Untangle, Reconcile and Interpret the Evidence. NBER, Working Papers: 7472.

Oppenheimer V. K. and Lewin A. (1997): Career Development and Marriage Formation in a Period of Rising Inequality: Who is at Risk? What are their Prospects? In: Booth A. et. al. (eds.) Transitions to Adulthood in a Changing Economy. Westport/London: Praeger, 189-225

Ormel J. (2002): Social production function (SPF) theory as a heuristic for understanding developmental trajectories and outcomes. In Pulkkinen L. and Caspi A. (eds.): Paths to successful development, New York: Cambridge University Press, 353 - 379.

Pappi U. F. (ed.). 1979: Sozialstrukturanalysen mit Umfragedaten. Königstein: Athenäum Verlag.

Pfau-Effinger B. (2000): Kultur und Frauenerwerbstätigkeit in Europa. Theorie und Empirie des internationalen Vergleichs. Opladen: Leske + Budrich.

Schaeper H. and Kühn T. (2000): Zur Rationalität familialer Entscheidungsprozesse am Beispiel des Zusammenhangs zwischen Berufsbiographie und Familiengründung. In: Zeitschrift für Soziologie der Erziehung und Sozialisation, 3 (Beiheft 2000), 124-145.

Sennett R. (1998): The corrosion of character: the personal consequences of work in the new capitalism. New York: Norton. 
Soskice D. (1993): The Institutional Infrastructure for International Competiveness: A Comparative Analysis of the UK and Germany. In: Atkinson A. B. and Brunetta R. (eds.): The Economics of the New Europe. London: MacMillan, 45-66.

Strengmann-Kuhn W. (2000): Erwerbstätigkeit und Einkommensarmut: Armut trotz Erwerbstätigkeit. In: Büchel F. et. al. (eds.): Zwischen Drinnen und Draußen. Arbeitsmarktchancen und soziale Ausgrenzung in Deutschland. Opladen: Leske + Budrich, 139-151.

Tölke A. and Diewald M. (2003): Berufsbiographische Unsicherheiten und der Übergang zur Elternschaft bei Männern. In: Bien W. and Marbach J. (eds.): Partnerschaft und Familiengründund. Analysen der dritten Welle des Familiensurveys 2000. Opladen: Leske + Budrich, 349-384.

Thomson E. (1997): Her, his and their children: Influences on couple childbearing decisions. In: NSFH Working Paper No.76.

van de Kaa D. (1999): The past of Europe's demographic future. In: European Review, 7, 529-550.

Zedeck S. (1992): Introduction: Exploring the Domain of Work and Family Concerns. In: Zedeck S. (ed.): Work, Families and Organizations. San Francisco: JosseyBass Publishers, 8-22. 
Table A1: Transformation of the „Occupational Status Classification into Career Ranks

\begin{tabular}{|c|c|c|c|c|c|c|c|c|}
\hline \multirow[b]{2}{*}{ Occupational status classification } & \multicolumn{8}{|c|}{ Career Rank } \\
\hline & 1 & 2 & 3 & 4 & 5 & 6 & 7 & 8 \\
\hline \multicolumn{9}{|l|}{ Worker (skill level) } \\
\hline unskilled & $x$ & & & & & & & \\
\hline semiskilled & & $\mathrm{x}$ & & & & & & \\
\hline skilled & & & $x$ & & & & & \\
\hline foremen & & & & $x$ & & & & \\
\hline master craftsman & & & & & & $x$ & & \\
\hline \multicolumn{9}{|l|}{ Employee (duties) } \\
\hline industry foreman & & & & & & $x$ & & \\
\hline simple & & $x$ & & & & & & \\
\hline qualified & & & & & $x$ & & & \\
\hline highly professional, independent & & & & & & $x$ & & \\
\hline highly professional, limited managerial & & & & & & & $x$ & \\
\hline extensive managerial & & & & & & & & $x$ \\
\hline \multicolumn{9}{|l|}{ Civil Servant } \\
\hline low level & & $x$ & & & & & & \\
\hline middle level & & & & & $\mathrm{x}$ & & & \\
\hline high level & & & & & & $x$ & & \\
\hline executive level & & & & & & & $1^{\text {st }}$ job & $2^{\text {nd }}$ or further job \\
\hline \multicolumn{9}{|l|}{ Self-employed (no. of employees) } \\
\hline free-lance, academic & & & & & & & & $x$ \\
\hline at most 1 (case-related solution/ exclusion) & & & & & & & & \\
\hline 9 or less & & & & & & & $x$ & \\
\hline 10 or more & & & & & & & & $x$ \\
\hline
\end{tabular}

Table A2: $\quad$ First job in relation to the educational level

- Position in the first job is below the educational level: - negative start - Position in the first job is above the educational level: + positive start

\begin{tabular}{|c|c|c|c|c|c|c|c|c|}
\hline & \multicolumn{8}{|c|}{ Career Rank } \\
\hline Education & 1 & 2 & 3 & 4 & 5 & 6 & 7 & 8 \\
\hline 1 Lower sec. school, no occupational training & & & + & + & + & + & + & + \\
\hline 2 Intermediate school, no occupational training & - & & + & + & + & + & + & + \\
\hline 3 Upper sec. school, no occupational training & - & - & & & + & + & + & + \\
\hline $\begin{array}{l}4 \text { Apprenticeship, lower sec./ intermediate school plus } \\
\text { business training }\end{array}$ & - & - & & & & + & + & + \\
\hline $\begin{array}{l}5 \text { Business training ( } 3 \text { years), Upper sec. school and } \\
\text { business ( } 2 \text { years) }\end{array}$ & - & - & - & - & & + & + & + \\
\hline 6 Technical college & - & - & - & - & & + & + & + \\
\hline 7 University degree & - & - & - & - & - & & & + \\
\hline
\end{tabular}


Table 1: Distribution of respondents in the sample and of fathers by selected variables (in percent)

\begin{tabular}{|c|c|c|c|}
\hline Covariates & Characteristics & All Respondents & Fathers \\
\hline \multirow[t]{5}{*}{ Birth-cohorts (age in 2000) } & $1946-1950(50-54)$ & 18 & 70 \\
\hline & $1951-1955(45-49)$ & 17 & 66 \\
\hline & $1956-1960(40-44)$ & 21 & 68 \\
\hline & 1961-1965 (35-39) & 25 & 56 \\
\hline & $1966-1970(30-34)$ & 20 & 43 \\
\hline \multirow[t]{4}{*}{ Denomination } & Protestant & 41 & 59 \\
\hline & Catholic/other Christian denomination & 39 & 63 \\
\hline & Islam /non-Christian denomination & 3 & 79 \\
\hline & Atheist/ no answer & 17 & 52 \\
\hline \multirow[t]{3}{*}{ Grown up with parents up to age 16} & With parents & 92 & 61 \\
\hline & Divorced parents/unmarried & 6 & 51 \\
\hline & Death of a parent & 2 & 43 \\
\hline \multirow[t]{2}{*}{ Siblings } & Yes & 81 & 66 \\
\hline & No & 19 & 46 \\
\hline \multirow[t]{4}{*}{ Father's educational qualification } & Rest & 79 & 63 \\
\hline & Intermediate/ upper sec. school + & & \\
\hline & educational training & 15 & 49 \\
\hline & University degree & 7 & 45 \\
\hline \multirow[t]{7}{*}{ Own educational qualification } & Lower sec. school, no training & 10 & 67 \\
\hline & Lower sec. school, training & 39 & 62 \\
\hline & Intermediate school, no training & 5 & 54 \\
\hline & Intermediate school, training & 23 & 63 \\
\hline & Upper sec. school, no training & 5 & 51 \\
\hline & Upper sec. school, training & 5 & 58 \\
\hline & Upper sec. school, university & 12 & 57 \\
\hline \multirow[t]{2}{*}{ Start positive } & Yes & 87 & 60 \\
\hline & No & 13 & 68 \\
\hline \multirow[t]{2}{*}{ Start negative } & Yes & 89 & 60 \\
\hline & No & 11 & 57 \\
\hline \multirow[t]{3}{*}{ Permanent contract } & Since the beginning $/$ in $1^{\text {st }}$ year & 93 & 60 \\
\hline & In 2nd or 3rd year & 2 & 56 \\
\hline & in 4 th year or later & 7 & 56 \\
\hline \multirow[t]{2}{*}{ Full-/part-time in $1^{\text {st }}$ job } & Fulltime & 96 & 61 \\
\hline & Part-time & 4 & 44 \\
\hline \multirow[t]{2}{*}{ Self-employed in one of the first jobs } & Not self-employed & 94 & 61 \\
\hline & Self-employed & 7 & 42 \\
\hline \multirow{3}{*}{$\begin{array}{l}\text { Interruption of employment because of } \\
\text { education until } 1^{\text {st }} \text { child/interview }\end{array}$} & & & \\
\hline & Yes & 6 & 52 \\
\hline & No & 94 & 60 \\
\hline \multirow{3}{*}{$\begin{array}{l}\text { Interruption of employment for reasons } \\
\text { other than education until } 1^{\text {st }} \text { child/interview }\end{array}$} & & & \\
\hline & Yes & 13 & 35 \\
\hline & No & 87 & 64 \\
\hline \multirow[t]{5}{*}{ Professional career until $1^{\text {st }}$ child/ interview } & Upward mobile & 20 & 49 \\
\hline & Downward mobile & 2 & 36 \\
\hline & Upward-downward mobile & 1 & 31 \\
\hline & Downward-upward mobile & 1 & 58 \\
\hline & No change & 76 & 64 \\
\hline $\mathrm{N}$ of cases & & 1600 & 1600 \\
\hline
\end{tabular}


Table 2: $\quad$ Relative risks of transition to first fatherhood (Cox-Regression)

Models 1 and 2: Process-time since first entry into the labor market

Models 3 and 4: Process-time since first relationship after having entered the labor market

\begin{tabular}{|c|c|c|c|c|}
\hline & Model 1 & Model 2 & Model 3 & Model 4 \\
\hline \multicolumn{5}{|l|}{ Birth cohorts } \\
\hline $1946-50$ & 1.09 & .1 .19 & 1.14 & .98 \\
\hline $1951-55$ & .90 & .92 & .95 & .83 \\
\hline \multicolumn{5}{|l|}{ Ref.: $1956-60$} \\
\hline $1961-65$ & .83 & .84 & .83 & .97 \\
\hline $1966-70$ & $.73^{\star \star}$ & $.76^{*}$ & $.78^{*}$ & .96 \\
\hline \multicolumn{5}{|l|}{ Age (time-varying) } \\
\hline Younger than 20 & $.40^{\star *}$ & $.38^{* *}$ & $.41^{*}$ & .68 \\
\hline Age 20 to 24 & 1.02 & 1.01 & $.80^{*}$ & 1.03 \\
\hline \multicolumn{5}{|l|}{ Ref.: Age 25 to 29} \\
\hline Age 30 to 34 & 1.03 & 1.04 & 1.09 & .98 \\
\hline Age $35+$ & $.49^{\star *}$ & $.50^{\star \star}$ & $.58^{*}$ & $.53^{* *}$ \\
\hline \multicolumn{5}{|l|}{ Educational qualification } \\
\hline Lower sec. school, no training & 1.06 & 1.05 & 1.26 & 1.18 \\
\hline \multicolumn{5}{|l|}{ Ref.: Lower sec. school, training } \\
\hline Intermediate school, no training & .85 & .88 & .75 & .85 \\
\hline Intermediate school, training & 1.10 & $1.21^{*}$ & $1.21^{*}$ & $1.39^{* *}$ \\
\hline Upper sec. school, no training & 1.09 & 1.21 & 1.05 & $1.51^{*}$ \\
\hline Upper sec. school, training & 1.38 & $1.48^{*}$ & .1 .33 & 1.36 \\
\hline Upper sec. school, university & 1.23 & $1.36^{*}$ & 1.13 & 1.08 \\
\hline \multicolumn{5}{|l|}{ Start positive } \\
\hline \multicolumn{5}{|l|}{ Ref.: No } \\
\hline Yes & 1.02 & 1.07 & 1.13 & 1.06 \\
\hline \multicolumn{5}{|l|}{ Start negative } \\
\hline \multicolumn{5}{|l|}{ Ref.: No } \\
\hline Yes & 1.01 & 1.03 & 1.07 & 1.16 \\
\hline \multicolumn{5}{|l|}{ Permanent contract } \\
\hline \multicolumn{5}{|l|}{ Ref.: Since the beginning/in $1^{\text {st }}$ year } \\
\hline In 2 nd or 3 rd year & .88 & .87 & .74 & .70 \\
\hline In 4th year or later & 1.01 & 1.03 & .85 & .90 \\
\hline \multicolumn{5}{|c|}{$\begin{array}{l}\text { Interruption of employment because of education } \\
\text { (time-varying) }\end{array}$} \\
\hline \multicolumn{5}{|l|}{ Ref.: No } \\
\hline Yes & $.39^{\star *}$ & $.40^{* *}$ & .50 & .87 \\
\hline \multicolumn{5}{|c|}{$\begin{array}{l}\text { Interruption of employment not for education (time- } \\
\text { varying) }\end{array}$} \\
\hline \multicolumn{5}{|l|}{ Ref.: No } \\
\hline Yes & $.53^{* *}$ & $.52^{* *}$ & $.55^{*}$ & .83 \\
\hline \multicolumn{5}{|l|}{ Full-/part-time (in one of the first jobs) } \\
\hline \multicolumn{5}{|l|}{ Ref.: Full time } \\
\hline Part time & $.65^{*}$ & $.63^{*}$ & .71 & .83 \\
\hline \multicolumn{5}{|l|}{ Professional career (time-varying) } \\
\hline \multicolumn{5}{|l|}{ Ref.: No change } \\
\hline Upward mobile & $1.30^{* *}$ & $1.25^{\star *}$ & $1.26^{*}$ & $1.27^{*}$ \\
\hline Downward mobile & 1.22 & 1.18 & 1.36 & 1.23 \\
\hline Down-upward mobile & 1.01 & 1.25 & 1.06 & 1.23 \\
\hline Up-downward mobile & .58 & .59 & .33 & .57 \\
\hline
\end{tabular}


Demographic Research - Volume 9, Article 3

\begin{tabular}{|c|c|c|c|c|}
\hline & Model 1 & Model 2 & Model 3 & Model 4 \\
\hline \multicolumn{5}{|l|}{ Self-employed in (in one of the first jobs) } \\
\hline \multicolumn{5}{|l|}{ Ref.: Not self-employed } \\
\hline Self-employed & $.54^{* *}$ & $.54^{\star \star}$ & $.50^{* *}$ & $.55^{\star *}$ \\
\hline \multicolumn{5}{|l|}{ Denomination } \\
\hline \multicolumn{5}{|l|}{ Ref.: Protestant } \\
\hline Catholic/ other Christian religion & & 1.11 & 1.09 & 1.02 \\
\hline Islam /non-Christian religion & & $1.86^{* *}$ & $1.56^{*}$ & 1.15 \\
\hline Atheist/ no answer & & .82 & .83 & .84 \\
\hline \multicolumn{5}{|l|}{ Grown up with parents up to age 16} \\
\hline \multicolumn{5}{|l|}{ Ref.: With parents } \\
\hline Divorced parents/unmarried & & .83 & .78 & .87 \\
\hline Death of a parent & & $.55^{\star}$ & $.49^{*}$ & $.55^{\star}$ \\
\hline \multicolumn{5}{|l|}{ Siblings } \\
\hline \multicolumn{5}{|l|}{ Ref.: No } \\
\hline Yes & & $1.56^{* *}$ & $1.49^{\star \star}$ & $1.60^{\star *}$ \\
\hline \multicolumn{5}{|l|}{ Father's educational qualification } \\
\hline \multicolumn{5}{|l|}{ Ref.: Rest } \\
\hline \multicolumn{5}{|l|}{ Intermediate/ upper secondary } \\
\hline school + educational training & & .82 & $.79^{*}$ & $.75^{\star}$ \\
\hline University degree & & .75 & .72 & .74 \\
\hline \multicolumn{5}{|l|}{ Status of relationship(time-varying) } \\
\hline \multicolumn{5}{|l|}{ Ref.: Living-apart-together } \\
\hline Cohabitation & & & & $2.17^{\star *}$ \\
\hline Married & & & & $9.43^{* *}$ \\
\hline $\mathrm{N}$ of cases & 1600 & 1600 & 1286 & 1268 \\
\hline Log-likelihood & 13166 & 13098 & 10875 & 10734 \\
\hline
\end{tabular}

Note:

Significant: ${ }^{*} p<0.05 ;{ }^{* *} p<0.001$ 
Demographic Research - Volume 9, Article 3 